\title{
FORGÁCSOLT FELÜLETEK TOPOGRÁFIÁJÁNAK MEGHATÁROZÁSA KOORDINÁTA MÉRŐGÉP SEGÍTSÉGÉVEL
}

\section{DETERMINING THE TOPOGRAPHY OF MACHINED SURFACES BY COORDINATE MEASURING MACHINE}

\author{
Sándor Roland ${ }^{1 *}$ \\ ${ }^{1}$ Járműtechnológia Tanszék, GAMF Müszaki és Informatikai Kar, Neumann János Egyetem, Magyarország \\ https://doi.org/10.47833/2020.2.ENG.007
}

\section{Kulcsszavak: \\ felületi topográfia \\ koordináta méréstechnika \\ vizuális programozás}

\section{Keywords:}

surface topology

coordinate measuring technique

visual programing

\section{Cikktörténet:}

Beérkezett 2020. május 15.

Átdolgozva 2020. június 30.

Elfogadva 2020. július 5.

\begin{abstract}
Összefoglalás
A cikk egy lehetséges megoldást közöl forgácsolt felületek topográfiájának felvételére koordináta mérőgépen, kapcsoló típusú méröfejjel. Ennek elönye, hogy gyorsabb, hátránya pedig, hogy pontatlanabb a szokásos eljárásoknál. A cikk tárgyalja a mérések pontosságát, az alkalmazhatóság határait, valamint azt hogy a mérés eredményeit milyen módon tudjuk ábrázolni és értelmezni.
\end{abstract}

\begin{abstract}
The paper provides a possible solution for get topography of machined surfaces on a coordinate measuring machine with a touch trigger probe. The advantage of this is that it is faster and the disadvantage is that it is less accurate than standard procedures. This article discusses the accuracy of measurements, the limits of applicability, and how we can represent and interpret measurement results.
\end{abstract}

\section{Bevezetés}

Felületi topográfia alatt gyártott felületek nagy felbontású leképzését értjük (1.ábra). Ennek jelentősége abban rejlik, hogy ily módon lehetségessé válik a felület részletekbe menő elemzése. Így nagy pontossággal tudjuk jellemezni az adott gyártási technológia pontossági mérőszámait. Céljainktól függően változhat a felületen felvett pontfelhő felbontása és a felvett pontok mérésének bizonytalansága is. A cikkben tárgyalt módszer segítségével jól jellemezhetők durván megmunkált forgácsolt felületek, azonban finom megmunkálással létrehozott alaksajátosságok vizsgálatára nem alkalmas. Mindenképpen megkell jegyezni azonban hogy hátrányai mellett a tárgyalt eljárás rugalmasabb és bizonyos esetekben gyorsabb a hagyományos eljárásoknál.

\footnotetext{
* * Kapcsolattartó szerző. E-mail cím: sandor.roland@gamf.uni-neumann.hu
} 

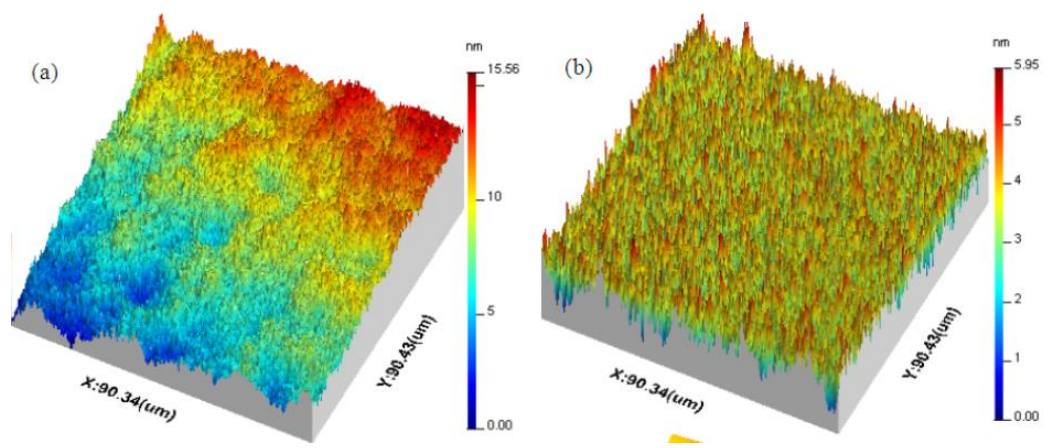

1. ábra Felületi topográfiai diagramm

A felületi topográfia felvételének két elterjedt módja ismeretes. A felületi érdességmérőgépen történő mérés esetén (2.ábra) több keresztmetszetben történik a profilmérés és az egyes mért profilok összefüzésével jön létre a vizsgált felület topográfiája. Ahhoz hogy ez a módszer alkalmazható legyen, olyan berendezés szükséges, amely képes két tengely mentén pozícionálni a vizsgált tárgyat. A másik módszer során egy nagyfelbontású lézer interferometrikus felületvizsgáló berendezésre van szükség (3.ábra). Ennek a módszernek a nagy elönye, hogy érintkezés nélkül mérjük meg a felületeket.

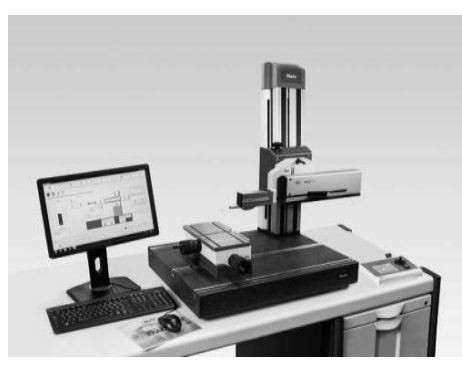

2. ábra Felületi érdesség mérő gép

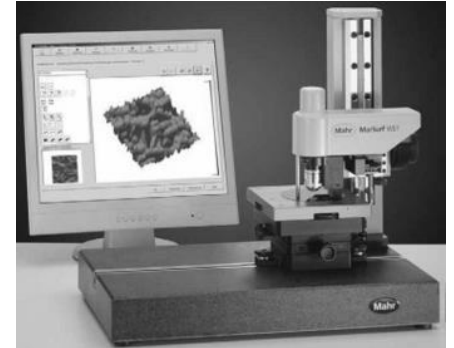

3. ábra Nagyfelbontású lézer-interferometrikus felületvizsgáló berendezés

\section{Felületi topográfia meghatározása koordinátamérögép segítségével}

A szokványos módszerekkel szemben durván megmunkált felületek topográfiájának felvételére kapcsoló típusú mérőfeljel felszerelt koordináta mérőgépek (4.ábra) is alkalmasak lehetnek. A kisérletek során használt mérőgép egy pont felvételi bizonytalansága 1,5 $\mu \mathrm{m}$. Ez azt jelenti, hogy finoman megmunkált felületek helytálló mérésére nem alkalmas azonban olyan felületek esetén igen, melyek várható alakhibái a századmilliméteres tartományba esnek. A kisérletek során használt berendezést vezérlő szoftver nem képes előre tárolt ciklus formájában lineáris kiosztásban egymástól független pontokat felvenni a vizsgálandó felületen. Ennek megfelelően az első lépésben egy olyan paraméteres ciklusprogram megírása szükséges mely sok oldalúan használható és változtatható paraméterekkel képes elvégezni a vizsgálat alapját képző méréseket. A paraméteres ciklusprogram készítése során irányelv volt, hogy több féle kialakítású munkadarab mérésére is alkalmas legyen. Ennek megfelelöen a program kezdőparaméterei között szerepel egy kezdőpont $x, y$ és $z$ koordinátája is mely segítségével a ciklus az első lépésben a gépi koordinátarendszert a munkadarab megadott pontjára transzformálja át. Ezt követően a második lépésben a munkadarabon meghatározott koordinátarendszerben értelmezett pozíciót adhatunk meg mely a vizsgált felület bal alsó pontját adja meg. A harmadik lépés a mérési pontok távolságának és számának megadását követően a ciklus program automatikusan felveszi a felületen az egymástól független mérési pontokat $A z$ így kapott 3D-s pontfelhöt exportálhatjuk és felhasználhatjuk az eredmények ábrázolására. 


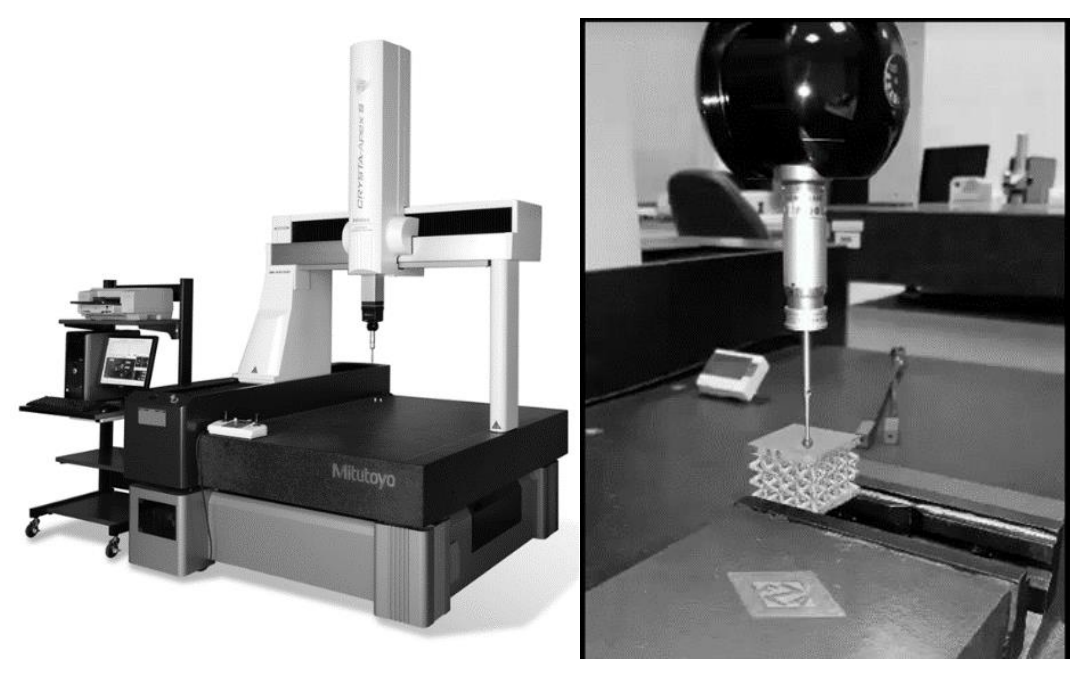

2. ábra 3D Koordinátamérőgép és annak kapcsoló típusú tapintója

\section{A mért adatok ábrázolása}

A mérések során használt koordinátamérőgép szoftvere nem alkalmas egy felületen felvett nagyszámú mérési pont felületként történő megjelenítésére. Ez jelentősen megnehezíti a mérési eredmények értelmezését $A$ mérési pontok megjelenítésére azonban a vizuális programozás eszközeit nagy hatékonysággal alkalmazhatjuk. A vizuális programozás eszközei lehetővé teszik, hogy a felhasználó egy szoftver alapeszközeit tetszőleges módon kombinálva saját algoritmusokat készítsen programozói háttérismeret nélkül. A mérési pontokat ábrázoló diagrammot (5.ábra) létrehozó algoritmus elkészítése a Rhinoceros 3D nevü szoftver Grasshopper névre hallgató moduljában történt. Az említett modul lehetővé teszi, hogy a felhasználó az alapszoftver eszközeit elérje funkció blokkok formájában. Minden funkcióblokknak vannak kimenetei és bemenetei. A funkció blokkok ki és bemeneteit vonalakkal köthetjük össze ezzel adva meg a blokkok közötti kapcsolat jellegét. Az elérhető blokkok között vannak, amelyek egészen egyszerü müveleteket végeznek, például összeadják a bemenetekre kötött szám jellegü változókat, és vannak egészen bonyolultak is melyek iterációs számítást végeznek egy célparaméter elérése érdekében. Ez a blokkdiagrammos felépítés lehetővé teszi paraméteres ábrák elkészítését is. Ebben a konkrét esetben a mérési pontkoordináták megnyitása után lehetőség van módosítani a színskálát, a skálaosztást a $z$ irányú koordináták nagyítását valamint a diagram megjelenítésének térszögeit. $A$ vizsgált felület határait az algoritmus a mérési pontok koordinátái alapján felismerik így a diagramm a mért felület nagyságától függetlenül képes ábrázolni eredményeinket.

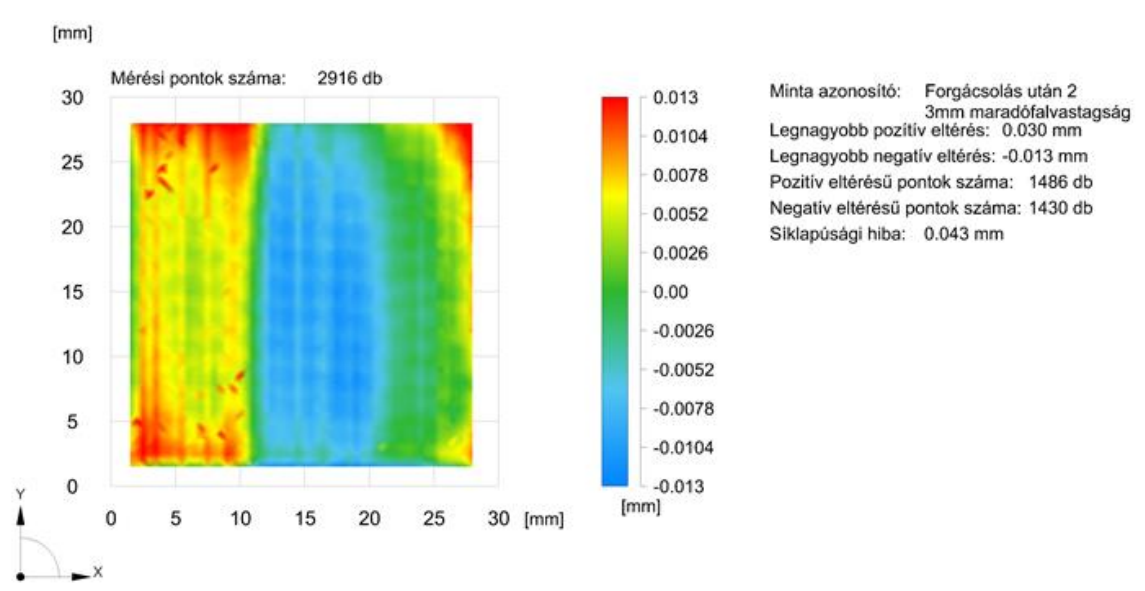

3. ábra Felületi topográfia ábrázolása 


\section{Az algoritmus müködése}

A példa gyanánt készített algoritmus párhuzamos műveletek egész sorát végzi el, azonban a műveletek funkcióit tekintve jól elkülöníthető lépéseket határozhatunk meg. Az első lépésben megtörténik a mérési pontok koordinátáinak betöltése, melynek alapja a koordináta mérögép szoftvere által exportált txt file. Az így kapott pontfelhőt a szoftver háromszögekkel burkolja, így adatvesztés vagy torzulás nélkül egy felületi képet kapunk a mért felületröl. Ezt követően meghatározásra kerül a felület alapsíkja, melyet az algoritmus a legkisebb négyzetek elven számol ki a mérési pontok z koordinátáiból. Miután meghatározásra került az alapsík, a mérési pontok alapsíktól vet távolsága már könnyen meghatározható. Az így kapott távolság komponensek a névleges geometriától, egy tökéletes síktól, való eltérést, devianciát testesítik meg az egyes mérési koordinátákon. Ezeket a távolság komponenseket ezután tetszőleges számú és nagyságú tartományra bonthatjuk. A tartományok meghatározását alapértelmezetten a legnagyobb és legkisebb deviancia alapján meghatározott tartomány általunk meghatározott számú vagy nagyságú egyenlő tartományokra való bontásával végzi az algoritmus, de lehetőség van aszimmetrikus tartomány eloszlás létrehozására is ha ezt igényli az adott feladat. Az így kapott tartományokhoz egy formázó funkcióblokk segítségével színskálát rendelünk melynek paraméterei szintén tetszőlegesen módosíthatók. A gyakorlatban a mérési pontjaink felületre normális $z$ irányú eltérései a századmilliméteres tartományba esnek. Ez azt jelenti, hogy a felületi textúra egyenetlenségei 1:1 méretarányban nem szemléltethetők kielégítő módon. Ezen probléma megoldására az algoritmus a megjelenített felület alapjául szolgáló pontok z koordinátáit egy tetszöleges számmal megszorozza és így már szabad szemmel is jól láthatóak a felületi egyenetlenségek a megjelenített diagramon. Fontos azonban, hogy a tartományok meghatározása, valamint a későbbi kiértékelést segítő számítások elvégzése során az algoritmus az eredeti, exportált pontok koordinátáit veszi figyelembe. Ha nem így lenne, akkor a nagyítási tényező megváltoztatásával megváltoznának a felület hibáját jelezni hivatott számértékek és a színskála is torzulna a nagyított értékeknek megfelelően.

Fontos, hogy a mérések elött még nem tudjuk, hogy a felület textúrájának jellege hogyan fog alakulni. Statikus diagram esetén tehát könnyen elöfordulhat, hogy az algoritmus által létrehozott diagram nem szemléletes, átláthatatlan mert a létrehozott felület bizonyos pontjai egy adott nézetböl takarják a felület más pontjait. Ennek kiküszöbölése érdekében az algoritmus lehetőséget biztosít a diagram tetszöleges pozícióba forgatására. Így a kapott felületet lehetőségünk van megvizsgálni valamely alapsíkból nézve, vagy akár izometrikus ábrázolási módban is. További segédfunkció, hogy az algoritmus egy általunk meghatározott osztású rácsot rajzol a diagramra és így az ábrából egyértelmúen meghatározható a vizsgált felület nagysága. A rács határai az exportált mérési pontok koordinátái alapján automatikusan kerülnek meghatározásra, így a felhasználónak csupán a rács osztását kell megadni.

Az így kapott diagram számszerüsített értékek nélkül, mérnöki felhasználásra alkalmatlan lenne. Ennek megfelelően az algoritmus meghatározza a mérési pontjain legfontosabb számszerüsíthető jellemzőit is. Ilyen módon a felhasználó információt kap a mérési pontok számáról, az alapsíktól mért legnagyobb pozitív és negatív devianciáról, az alapsíkhoz képest negatív és pozitív eltérésű pontok számáról valamint a síklapúsági hiba mértékéről is.

A felületi textúra elemzésének megkönnyítésére a tárgyalt algoritmus automatikusan elkészít a vizsgált felületről egy árnyékolt nézetet is. A 6.ábra egy mart felületet ábrázol, melyen az árnyékolt nézetnek köszönhetöen felismerhetö a hullámos mintázat mely a megmunkálás közben létrejött rezgések következménye. 


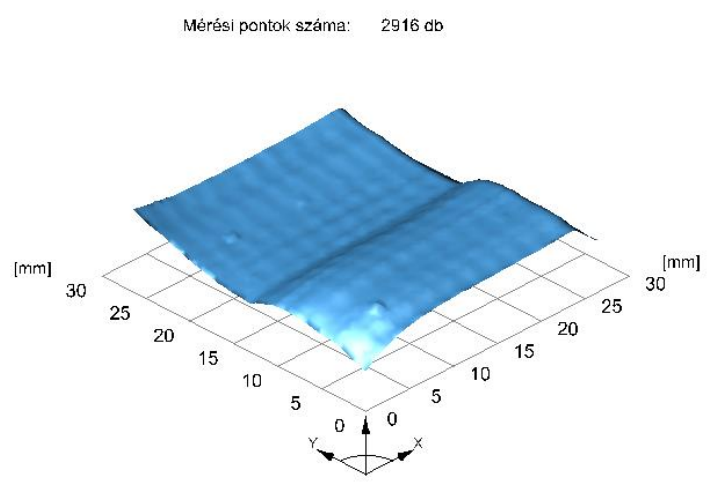

4. ábra Vizsgált felület árnyékolt nézete

\section{Köszönetnyilvánítás}

A projekt az Európai Unió támogatásával, az Európai Szociális Alap társfinanszírozásával valósul meg. EFOP-3.6.1-16-2016-00014

The project has been supported by the European Union, co-financed by the European Social Fund. EFOP-3.6.1-16-2016-00014.

\section{Irodalomjegyzék}

[1] Measurement Good Practice Guide No. 108

Guide to the Measurement of Smooth Surface Topography using Coherence Scanning Interferometry pp23

[2] Mahr termékkatalógus 2019

https://www.mahr.com/ (Utolsó letöltés: 2019. 09. 10.)

[3] Measurement Good Practice Guide No. 108

Guide to the Measurement of Smooth Surface Topography using Coherence Scanning Interferometry pp7

[4] Mitutoyo termékkatalógus 2019

https://mitutoyo.hu/hu_hu/ (Utolsó letöltés: 2019. 09. 10.) 